\title{
A Model To Estimate Firms' Accounting-Based Performance: A Data Envelopment Approach
}

Merwe Oberholzer, North-West University, South Africa

\begin{abstract}
The objective of the study was to follow a logical inductive approach to develop a Data Envelopment Analysis (DEA) model to estimate the relative technical efficiency of firms. The Du Pont analysis theory as conceptual framework was applied using primarily readily available accounting line-items as input and output variables. From an interpretive epistemological paradigm and analytical reasoning, a new DEA model was developed with Weighted Average Cost of Capital (WACC), leverage and expenditure as input variables and revenue, net profit and Earnings Before Interest, Tax, Depreciation and Amortization (EBITDA) as output variables. The originality of this study is that this is the first effort to employ accounting data, based on the Du Pont analysis in a DEA model. All the input and output variables in the model were already used individually or in combinations by previous studies, except for WACC. The study argues that WACC should be employed as a proxy for the accounting line-items, equity and liabilities, since lowering WACC implies that firms are moving closer to their optimal capital structures.
\end{abstract}

Keywords: Du Pont Analysis; Data Envelopment Analysis; Accounting-based; Weighted Average Cost of Capital; EBITDA

\section{INTRODUCTION}

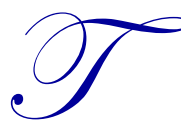

his study includes inductive theory building using Data Envelopment Analysis (DEA) to establish a new model to estimate the accounting-based performance of firms in terms of technical efficiency. Many DEA models already exist in literature where researchers selected appropriate variables (Ho et al., 2009). The importance of this study is that it questions the sensibility of variables in existing models by applying the Du Pont analysis theory as a conceptual framework, since the selection of variables is critical to the successful application of a DEA model (Min et al., 2009). Analysts and managers may apply this new model to estimate the relative efficiencies of firms and set benchmarks for underperforming firms. DEA is a non-parametric efficiency measurement technique, using linear programming to estimate a comparative ratio of weighted outputs to weighted inputs for each firm, usually referred to as a Decision-Making Unit (DMU). Furthermore, it lends itself to aggregate the relative performances of firms into a single measure where multiple inputs and multiple outputs are used. (Avkiran, 2011; Coelli et al., 2005.) Although DEA efficiency can be measured in terms of technical, allocative, scale and cost efficiencies, this study focuses on technical efficiency, which indicates how well inputs are converted into outputs (Coelli et al., 2005). The financial performance of firms consists of accounting-based (financial statement) and market-based performances (Agarwal \& Taffler, 2008). This study primarily focuses on accounting data because accounting measures are used to measure management performance. Furthermore, it provides a trustworthy indication of how well the management of firms performs, where no market values, of which managers have no or little control, are included. Accounting data consist of both nominal accounts, that is income and expenditure accounts, and the balance sheet section, that is assets, liabilities and equity (Myburg et al., 2011). 


\section{RESEARCH PROBLEM, OBJECTIVES AND METHODOLOGICAL PREFERENCES}

Accounting line-items in financial statements are meaningless on their own and have limitations. For example the information can only be expressed in monetary value and must be interpreted against the backdrop of the accounting policy (Correia et al., 2011). Accounting-based ratio analysis is a technique to further analyse financial statements that express a relationship between two accounting-line items. Like accounting line-items, accounting-based ratios also have weaknesses. For example the literature cannot agree upon the relative importance of the different ratios, it is only appropriate if firms focus on a single input or produce a single output (Chen, 2002) and no single financial ratio provides an adequate indication of the performance of firms (Halkos \& Salamouris, 2004). In context of this study the most significant weakness is the lack of objectivity and the lack of a suitable benchmark to compare the line-items or ratios against (Hassan Al-Tamimi \& Lootah, 2007).

Instead of focusing on individual accounting line-items researchers; therefore, developed multiple input multiple output financial statement-based DEA models where the relative performance of firms is aggregated into a single estimate. The input variables consist of accounting line-items such as assets, equity, expenses and output variables such as revenue and profit (Oberholzer; 2013; Ho \& Oh, 2010; Guzmán \& Arcas, 2008; Lo \& Lu; 2006; Luo, 2003; Seinford \& Zhu, 1999). Other researchers developed DEA models and use financial ratios as input and output variables in their models (Avkiran, 2011; Ablanedo-Rosas et al., 2010; Edirisinghe \& Zhang, 2007; Halkos \& Salamouris, 2004). Although DEA models (including accounting and non-accounting data) proved to be superior to financial ratios (Oberholzer, 2012a; Hassan Al-Tamimi \& Lootah, 2007; Halkos \& Salamouris, 2004; Yeh, 1996), a problem surfaces when developing accounting-based DEA models, the same 'weak' line-items and/or ratios are incorporated. Nevertheless, the strength of using DEA is that it aggregates a combination of line-items and/or ratios in a single model. The challenge is that a sensible combination of accounting data (and non-accounting data) are needed to develop a sensible DEA model; therefore, the question remains: What is a sensible DEA model? To summarise the problem, this study argues that when developing accounting-based DEA models, the weakness of lacking objectivity and lacking a suitable benchmark of the accounting line-items and/or ratios will to some extent be forwarded to the DEA model.

This study focuses on accounting data, because this kind of data is readily available. Non-accounting data such as number of employees, number of transactions, number of retail outlets and/or branches (Cronje, 2002), which are frequently used in DEA models, are not readily available. Therefore, by following a logical approach the objective of the study is to identify accounting line-items, ratios and other variables to develop an acceptable accounting-based DEA model. To assist this approach the Du Pont analysis is used as a conceptual framework as a basis to unravel accounting performance. This analysis indicates how the net profit margin and asset turnover affect return on assets, and how return on assets and leverage affect return on equity (Asaftei, 2008). It is a structured analysis measuring how effective firms are to achieve their objective of wealth maximization (Correia et al., 2011).

The epistemological paradigm preference for this study is rather interpretive than positivistic, since this is qualitative of nature where secondary sources are used to do a conceptual analysis as part of a building block to construct a new theory (Nieuwenhuis, 2013a). The role of this study is to develop a new DEA model without empirical testing that can be used by analysts and managers to estimate the relative technical efficiency of firms and to provide a basis to benchmark the performance of firms. Furthermore, an inductive data analysis approach will be followed, since interpretivism is more likely to assume that there are many realities (possible models), with an effort to reach the best possible outcome (Maree \& van der Westhuizen, 2013). In addition, inductive generalization will be done by analyzing sources within the conceptual framework, to apply inferences to theoretical populations (firms) (Mouton, 2011).

The remainder of the study will evolve as follows: The next section will explain DEA and will provide a literature review. This will be followed by sections that set the conceptual scope and an analytical discussion and relevant theories. The study will be finally concluded thereafter. 


\section{DATA ENVELOPMENT ANALYSIS}

\section{Definition And Evaluation}

DEA is a non-parametric efficient frontier technique that computes a comparative ratio of weighted outputs to weighted inputs for each DMU, which is reported as the relative efficiency score (Avkiran, 1999; 2011). The efficiency frontier, or envelope, is the foundation for the whole concept of DEA. The DEA identifies inefficiency in a particular unit by comparing it to similar units regarded as efficient (Avkiran, 1999). Non-parametric measure means "the branch of statistics that studies data measurable on an ordinal or nominal scale, to which arithmetic operations cannot be applied" (Collins English Dictionary, 2003). In other words, DEA compares the efficiency of how the same multiple inputs and the same multiple outputs are converted by a DMU, relative to other competing DMUs in the sample (Liu \& Wang, 2009; Min et al., 2009). The fundamental assumption of DEA is that if a DMU is capable of producing $Y(\mathrm{~A})$ units of output with $X(\mathrm{~A})$ inputs, then other DMUs should also be able to do the same if they were operating efficiently. The fundamental objective of the DEA modeling exercise is to find the 'best' virtual DMU for each real DMU and then to compare the DMU to its best virtual DMU in order to determine its efficiency. Analyzing the efficiency of a number of DMUs requires a formulation of a linear programming problem for each DMU to find the best virtual DMU (Anderson, 1996). This way the DEA can also be used to benchmark the best practice in a particular group of units (Avkiran, 1999). If the analyst knows which efficient units are most comparable to the inefficient unit, they will develop a better understanding of the nature of the inefficiencies and can re-allocate scarce resources in order to improve productivity (Avkiran, 1999). It creates a frontier of the best performing units within the dataset (Bowlin \& Renner, 2008), which consist of units that possess some common functional traits, but whose efficiency may vary due to internal differences (El-Mahgary \& Lahdelma, 1995). Its main usefulness lies in its ability to identify units to benchmark against and to generate potential improvements for inefficient units (Avkiran, 1999).

The concept of establishing a satisfactory measure for productive efficiency that takes account of all inputs was first introduced by Farrell (1957). In response of the challenge laid down by Farrell, Charnes et al. (1978) developed the CCR (Charnes, Cooper \& Rhodes) model, which was to estimate the production function either through a parametric approach or by using non-parametric linear technology (Avkiran \& Rowlands, 2008), which was based on the assumption of Constant Return to Scale (CRS) (Alvandi et al., 2013). Using CRS, a DMU is automatically considered fully scale efficient (Theunissen, 2012; Coelli et al., 2005), because it implies a proportionate rise in outputs when inputs are increased, or in other words, a DMU's efficiency is not influenced by the scale of its operations (Avkiran, 1999). Banker et al. (1984) developed the BCC (Banker, Charnes \& Cooper) model, which is an extension of the CCR model (Alvandi et al., 2013), which accommodates Variable Return to Scale (VRS) that implies a disproportionate rise or fall in outputs when inputs are increased, or in other words, if a scenario grows in size, its efficiency will not remain constant, but it will either rise or fall (Avkiran, 1999).

The DEA allows the analyst to select multiple inputs and outputs in accordance with a managerial focus and it can work with variables of different units without the need for standardization (that is monetary value, percentage, number of employees, and so forth). This process involves identifying performance variables (outputs) that reflect the corporate objectives and strategies of companies and then determining the input variables that can be demonstrated to manifest themselves as outputs (Avkiran, 1999). This characteristic is especially useful in this study which allows for a combination of accounting line-items and ratios as input components and output components. Furthermore, there are no multi-co linearity problems with the DEA as there are with regression analysis, so variables that measure similar performance elements, for example gross profit and net profit, can be used simultaneously in the model (Bowlin \& Renner, 2008). Another common practice in DEA is to allow the optimization programme to determine the weights for each variable included in the model; however, it is possible to restrict the weight of variables if management is concerned that a variable might be under- or over-represented (Avkiran, 1999).

The analyst also has the model options of input minimization and output maximization with the DEA. Input minimization (input-orientated approach) examines the extent to which inputs can be reduced while maintaining output levels. Potential improvements indicated by the DEA may suggest increasing outputs and lowering inputs at 
the same time if output slacks depict under-produced outputs. Alternatively, output maximization (output-orientated approach) investigates the extent to which outputs can be raised given current input levels.

The most important limitation of the DEA is that it assumes data to be free of measurement error. If the integrity of data has been violated, DEA results cannot be interpreted with confidence because the efficiency scores of units both on and under the frontier will be biased. A second limitation of the DEA is that those units indicated as efficient are only efficient in relation to others inside the sample (Avkiran, 1999). Thirdly, the DEA is a good indicator of relative efficiency, but not absolute efficiency. In other words, it indicates how well a unit is doing compared to its peers, but not compared to a theoretical maximum (Anderson, 1996). Furthermore, the DEA will not discriminate well if the ratio of units to the product of inputs and outputs is low, because most units would simply appear as efficient and lie on the frontier (Avkiran, 1999). To summarize, DEA is a useful tool in setting targets for inefficient units to improve performance, but the drawback is that it does not indicate to the analyst how to reach those targets or why the unit is not performing well.

\section{Model Formulation}

The DEA model presented by Zhu (2009), for both the input-orientated and output-orientated approaches, is used to demonstrate its calculation. These models are based on both CRS and VRS. A set of $n$ observations will be considered on the decision-making units (DMUs). Each observation, $\operatorname{DMU}_{j}(j=1, \ldots n)$, uses $m$ inputs $x_{i j}(i=$ $1,2, \ldots, m)$ to produce $s$ outputs $y_{r j}(r=1,2, \ldots, s)$. The efficiency frontier will be determined by these $n$ observations. The mathematical formulations of the input- and output-orientated approaches are shown in Table 1. $D M U_{0}$ represents one of the $n$ DMUs under review and $x_{i 0}$ and $y_{r 0}$ are the $i$ th input and $r$ th output for $D M U_{0}$, respectively.

Table 1: DEA Models

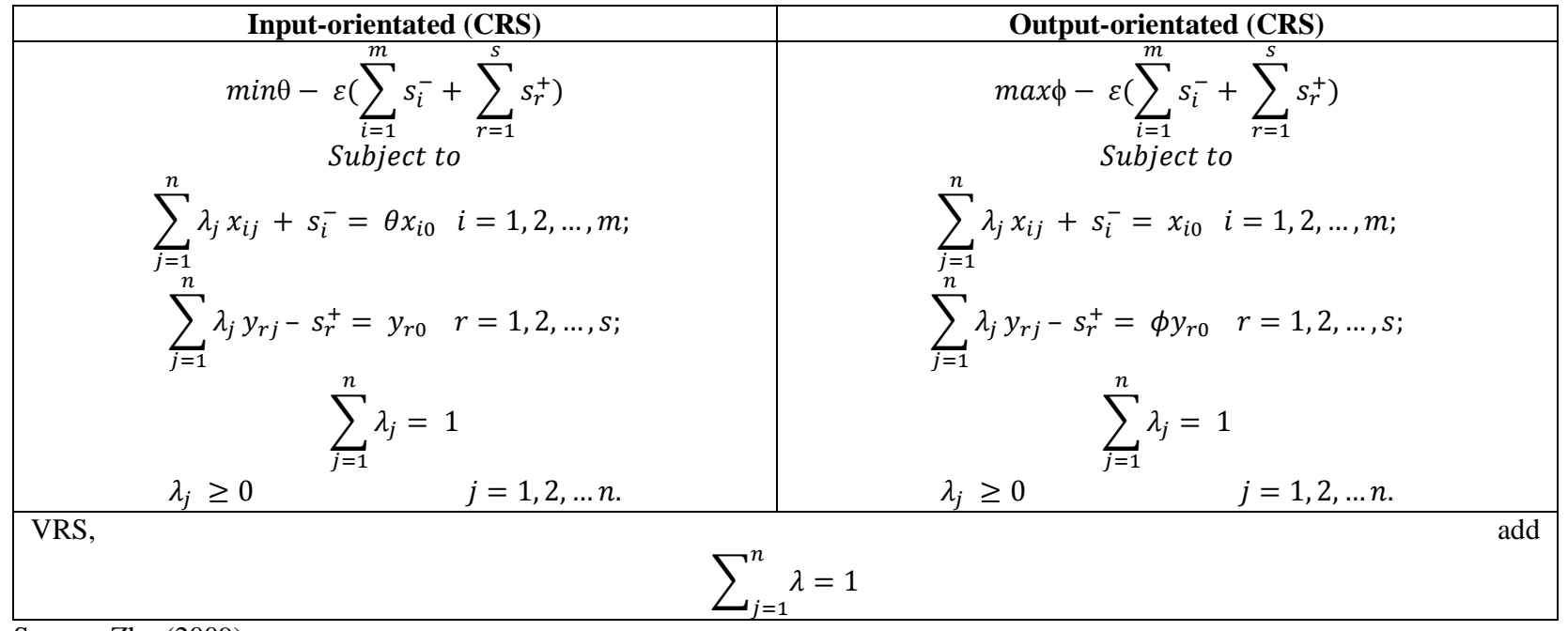

Source: Zhu (2009)

The value of $\theta$ represents the input-orientated efficiency score and $\phi$ the output-orientated efficiency score of $D M U_{0}$. If $\theta=1$ or $\phi=1, D M U_{0}$ lies on the frontier. If $\theta<1$ or $\phi>1, D M U_{0}$ is inefficient and should either decrease its input levels or increase its output levels. It is possible for the DEA to indicate an individual input reduction or output increase for a specific DMU in order to move it onto the frontier. These input reductions or output increases are called input or output slacks and are represented by $s_{i}^{-}$and $s_{r}^{+}$, respectively. The presence of $\varepsilon$ in the input-orientated model allows the minimization over $\theta$ to pre-empt the optimization involving the slacks, $s_{i}^{-}$ and $s_{r}^{+}$. The model is; therefore, calculated in a two-stage process. Firstly, maximal reduction of inputs is achieved by optimizing $\theta$. Secondly, movement onto the frontier is achieved by optimising the slack variables. Similarly, the output-orientated model is also calculated in a two-stage process by firstly calculating $\phi$ and then optimizing the slacks by fixing $\phi$. Ray (2004) clarifies slacks with a simple example: Suppose that in a particular application $\phi^{*}=1.25$ is obtained. This means that all the outputs should be increased by $25 \%$ for the company to become fully 
efficient. Now suppose that $s_{1}^{+^{*}}=10$. This implies that output ${ }_{1}$ can be further increased by 10 units. Moreover, if any one of the input slacks is strictly positive, the previous expansion of the outputs can be achieved while reducing individual inputs at the same time.

\section{LITERATURE REVIEW}

DEA is widely researched and applied in a variety of studies because it is suitable for multiple-inputmultiple-output firms. For example, studies previously used DEA to investigate the performance of banks, at both corporate level (Avkiran, 2011, Halkos \& Salamouris, 2004; Cronje, 2002; Devaney \& Weber, 2000; Berger \& Humphrey, 1997; Resti, 1997), and at branch level (Paradi et al., 2011; Van der Westhuizen, 2008; O'Donnell \& Van der Westhuizen, 2002; Sherman \& Ladino, 1995; Sherman \& Gold, 1985). Other DEA studies investigated for example firms involved in agriculture (Chiu et al., 2011; Murthy et al., 2009; Guzmán \& Arcas, 2008), financial services (Malhotra et al., 2008; Kao \& Hwang, 2008), software production (Asmild et al., 2006), hotels (Min et al., 2009), manufacturing firms (Liu \& Wang, 2009; Abad et al., 2004), ports (Ablanedo-Rosas et al., 2010), environmental issues (Oberholzer, 2012b; Yu \& Wen, 2010; Kuo et al., 2010; Lee et al., 2008; Munksgaard et al., 2005; Wier et al., 2005) and benchmarking (CEO) remuneration (Theunissen \& Oberholzer, 2013; Cordeiro et al., 2006).

DEA is also frequently used to investigate stock performances (and market performances) of firms (Alvandi et al., 2013; Gaganis et al., 2013; Pätäri et al., 2010; Javanmardi \& Lawryshyn, 2010), and more related to this study, firm internal performance (Wang et al., 2010; Edirisinghe \& Zhang, 2010) and both firm internal and market performance (Frijns et al., 2012; Oberholzer, 2012a; Ho et al., 2009; Ho \& Oh, 2010; Tsai et al., 2006; Zhu, 2000). The latter is related to this study since the investigation is to develop a new DEA model to aggregate internal performance by using accounting data. Analyzing the related studies will shed light on the input and output variables used in the existing models. These studies use both one stage and two stage DEA models.

As indicated above, many DEA studies were done in the banking sector. As the major operations of banks concern interest income and expenditure, non-interest income, loans and deposits, these variables are mostly included in the DEA models (Cronje, 2002); however, the studies of Seinford and Zhu (1999) and Luo (2003) investigated bank performance and did not use these variables, but used variables related to other studies that investigated non-banking firms. Table 2 provides a summary of the input and output variables used in the related studies.

Table 2 exhibits a variety of variables that were used in DEA models. In order to determine the relative efficiency of firms, some authors use a single-stage DEA model to determine the efficiency how inputs are converted into outputs. Other authors use a two-stage DEA model where the outputs of the first stage automatically form the inputs of the second stage. A one stage DEA model is relatively strong to indicate firm performance while a two-stage model is helpful to indicate the efficient use of resources and the effectiveness of output utilization (Wang et al, 2010). Most of the two-stage models, for example Lo and Lu (2006), Luo (2003) and Seinford and Zhu (1999), measure operational efficiency by means of the input and output variables as indicated in Table 2 . The outputs in Table 2 are the inputs for the second stage to measure marketability efficiency with outputs such as market value, stock price and earnings per share. Tsai et al. (2006) includes capital expenditure as an input variable. This will be interpretive as equity plus liabilities, and EBITDA (Earnings Before Interest and Tax, Depreciation and Amortization) will be interpreted as a variation of profit. 
Table 2: Input And Output Variables Used In Previous Studies

\begin{tabular}{|c|c|c|c|}
\hline Author & Inputs & Outputs & Model \\
\hline $\begin{array}{l}\text { Zhu, 2000, } \\
\text { Seinford \& Zhu (1999), } \\
\text { Luo (2003), and } \\
\text { Lo \& Lu (2006) }\end{array}$ & $\begin{array}{l}\text { Number of employees } \\
\text { Total assets } \\
\text { Book value of equity }\end{array}$ & $\begin{array}{l}\text { Revenue } \\
\text { Profit }\end{array}$ & $\begin{array}{l}\text { First stage of a two-stage } \\
\text { model }\end{array}$ \\
\hline Ho et al. (2009) & $\begin{array}{l}\text { Total assets } \\
\text { Total equity } \\
\text { Operating expense }\end{array}$ & $\begin{array}{l}\text { Revenue } \\
\text { Gross profit }\end{array}$ & $\begin{array}{l}\text { First stage of a two-stage } \\
\text { model }\end{array}$ \\
\hline Ho \& Oh (2010) & $\begin{array}{l}\text { Total assets } \\
\text { Total equity } \\
\text { Operating expense }\end{array}$ & $\begin{array}{l}\text { Revenue } \\
\text { Gross profit }\end{array}$ & Single-stage \\
\hline Wang et al. (2010) & $\begin{array}{l}\text { Finance: } \\
\text { Current assets } \\
\text { Fixed assets } \\
\text { Total assets } \\
\text { Capital } \\
\text { Equity } \\
\text { Operation: } \\
\text { Production capacity } \\
\text { Number of employees }\end{array}$ & $\begin{array}{l}\text { Finance: } \\
\text { Current liabilities } \\
\text { Long-term liabilities } \\
\text { Total liabilities } \\
\text { Operation costs } \\
\text { Operation expense } \\
\text { Operation: } \\
\text { Turnout }\end{array}$ & $\begin{array}{l}\text { First stage of a two-stage } \\
\text { model }\end{array}$ \\
\hline Wang et al. (2010) (cont.) & $\begin{array}{l}\text { Finance: } \\
\text { Current liabilities } \\
\text { Long-term liabilities } \\
\text { Total liabilities } \\
\text { Operation costs } \\
\text { Operation expense } \\
\text { Operation: } \\
\text { Turnout }\end{array}$ & $\begin{array}{l}\text { Finance: } \\
\text { Operation revenue } \\
\text { Operation gross } \\
\text { Operating income } \\
\text { Earnings before tax } \\
\text { Operation: } \\
\text { Revenue volume }\end{array}$ & $\begin{array}{l}\text { Second stage of a two-stage } \\
\text { model }\end{array}$ \\
\hline Oberholzer (2012a) & $\begin{array}{l}\text { Total expenditure } \\
\text { Tangible assets } \\
\text { Book value of equity }\end{array}$ & $\begin{array}{l}\text { Revenue value } \\
\text { Market value of equity } \\
\text { Dividend payouts }\end{array}$ & $\begin{array}{l}\text { Single stage model measuring } \\
\text { both operational and market } \\
\text { efficiency }\end{array}$ \\
\hline Frijns et al. (2012) & $\begin{array}{l}\text { Net property } \\
\text { Plant and equipment } \\
\text { Total long term debt } \\
\text { Total assets } \\
\text { Book value of equity } \\
\text { Capital expenditure } \\
\text { Cost of goods sold } \\
\text { General \& admin expenses }\end{array}$ & Revenue & $\begin{array}{l}\text { Single-stage model. Another } \\
\text { two models were used to } \\
\text { measure market efficiency } \\
\text { and both revenue and market } \\
\text { efficiency }\end{array}$ \\
\hline $\begin{array}{l}\text { Edirisinghe \& Zhang (2007) } \\
\&(2010)\end{array}$ & $\begin{array}{l}\text { Asset utilization } \\
\text { Liquidity } \\
\text { Leverage }\end{array}$ & $\begin{array}{l}\text { Profitability } \\
\text { Growth } \\
\text { Valuation } \\
\end{array}$ & (Discussion below) \\
\hline Tsai et al. (2006) & $\begin{array}{l}\text { Total assets } \\
\text { Capital expenditure } \\
\text { Number of employees }\end{array}$ & $\begin{array}{l}\text { Revenue } \\
\text { EBITDA } \\
\text { Operating profit }\end{array}$ & Single-stage \\
\hline
\end{tabular}

Edirisinghe and Zhang (2007) identified 18 ratios spread over six categories, namely profitability (return on equity, return on assets, profit margin and earnings per share), asset utilization (receivables turnover and asset turnover), liquidity (current ratio, quick ratio and debt to equity ratio), leverage (leverage ratio, solvency ratio-I and solvency ratio-II), valuation (price to earnings and price to book ratios) and growth (revenue growth rate, net income growth rate and earnings per share growth rate). Edirisinghe and Zhang (2010) used this as a basis for a DEA model and argue that profitability, valuation and growth can only be used as output variables and that asset utilization, liquidity and leverage can only be used as input variables for the DEA model.

In the study of Edirisinghe and Zhang (2007) \& (2010) valuation as an output variable and market value of equity (Oberholzer, 2012a) are components to measure marketability efficiency. Furthermore, Wang et al. (2010) includes non-accounting operation data in their model. These marketability and non-accounting data will not be 
considered to build a new DEA model, because the aim is to measure the management (internal) performances efficiency of firms. To summarize using only accounting data, the literature proposes the following aggregated inputs and outputs for a single stage or first-stage of a multiple-stage DEA model (Table 3):

Table 3: Summary Of Aggregated Input And Output Variables Used In Previous Studies

\begin{tabular}{|l|l|}
\hline \multicolumn{1}{|c|}{ Inputs } & \multicolumn{1}{|c|}{ Outputs } \\
\hline Assets (including current and non-current) & Revenue \\
Equity & Profit (including various types) \\
Expenditure (including cost of sales and general and & Growth \\
administration expenses) & Liabilities (including current and long-term) \\
Asset utilization & Expenditure (including cost of sales and general and \\
Liquidity & administration expenses) \\
Leverage (equity/assets) & \\
Liabilities (including current and long-term) & \\
\hline
\end{tabular}

It is evident in Table 3 that a numerous variety of accounting items are used in DEA models as input and output variables. It is also clear that liabilities and expenditure are used by some authors as input variables whilst other applied them as output variables; therefore, the open question can be repeated, namely: Which variables are sensible to be included as input and output variables in a DEA model focusing on accounting and/or related data?

\section{CONCEPTUAL SCOPE}

In this study the Du Pont analysis is used as a conceptual framework to reach the objective to unravel accounting-line items to develop an acceptable accounting-based DEA model. As mentioned, the Du Pont analysis indicates how the net profit margin and asset turnover affect return on assets, and how return on assets and leverage affect Return On Equity (ROE). The strength of the Du Pont analysis model is its ability to aggregate the performance of firms into three broad categories, namely income, investments and capital structure (Correia et al., 2011; Brigham \& Ehrhardt, 2006). The Du Pont analysis suggests that the internal performance of firms can be estimated by using the following accounting data, measuring ROE that summarizes all the nominal accounts included in the income statement and accounts from the balance sheet section of firms (Equation 1):

$\mathrm{ROE}=\frac{\text { net profit }}{\text { equity }}$

The net profit summarizes the income statement (net profit $=$ revenue - expenditure) and the equity (at book value) summarizes the balance sheet (equity $=$ assets - liabilities). To improve ROE, a combination of the following changes will be helpful (Equation 2):

$\mathrm{ROE}=\frac{\text { net profit } \uparrow}{\text { equity } \downarrow}$

From a DEA approach, the most technical efficient firms are those that can convert as little as possible equity (input) into as high as possible net profit (output). Following the arrows in Equation 2, it is also obvious that equity can only be an input while net profit can only be an output. Furthermore, from an input-orientated approach, an input such as equity can be reduced while maintaining the output level of net profit. From an output-orientated approach DEA investigates the extent to which profit as an output can be raised given current input level of equity. The Du Pont equitation can be further unraveled as follows (Equation 3):

ROE $=\frac{\text { assets }}{\text { equity }} \times \frac{\text { revenue }}{\text { assets }} \times \frac{\text { net profit }}{\text { revenue }}$

The asset/equity ratio represents the capital structure, revenue/asset ratio the investment and net profit/revenue the income (Correia et al., 2011). Note that liabilities, the third component in the balance sheet, are indirectly included since the accounting equation of liabilities = assets - equity, and any combination of the sum 
between equity and liabilities equals assets (Correia et al., 2011; Brigham \& Ehrhardt, 2006). Furthermore, the second component in the income statement expenditure is also indirectly included since expenditure $=$ revenue - net profit, and any combination of the sum between expenditure and net profit equals revenue (Correia et al., 2011; Brigham \& Ehrhardt, 2006). For firms to increase their ROE they should do a combination of the following (Equation 4):

ROE $=\frac{\text { assets } \uparrow}{\text { equity } \downarrow} \times \frac{\text { revenue } \uparrow}{\text { assets } \downarrow} \times \frac{\text { net profit } \uparrow}{\text { revenue } \downarrow}$

That implies the following three steps, namely to (i) convert as little as possible equity (input) into as high as possible assets (output), (ii) convert as little as possible assets (input) into as high as possible revenue (output), and (iii) to convert as little as possible revenue (input) into as high as possible net profit (output). To summarize, each of the three components (Equation 4) needs a high teller and a low denominator to increase the ROE, or in other words, when the denominator increases, the teller must increase more than the increase in the denominator, or when the denominator decreases, the teller must decrease less than the denominator. In conclusion, from the Du Pont analysis, equity can only be an input, because it can only be a denominator. Net profit can only be an output, because it can only be a teller. Both assets and revenue are denominators and tellers and; therefore, both can be an input and an output.

The logic business cycle is; therefore, that firms need equity to obtain assets, assets to generate revenue and revenue to make a profit (Equation 5):

equity $\rightarrow$ assets $\rightarrow$ revenue $\rightarrow$ net profit

To include liabilities and expenditure, the logical business cycle is that firms need capital (equity + liabilities) to obtain assets, and to incur expenditure to generate revenue and revenue to make a profit. The extended business cycle is as follows (Equation 6):

(equity + liabilities) $\rightarrow$ assets $\rightarrow$ expenditure $\rightarrow$ revenue $\rightarrow$ profit

To develop a new DEA model using accounting data, with the Du Pont analysis as framework, and including all the variables in Equation 6, the open questions, of what is a sensible DEA model, can be refined by adding the following questions, namely: How should assets and revenue be incorporated since Equation 4 suggest them to both be increased and be reduced? How should liabilities (debt) be incorporated? and How should expenditure be incorporated?

\section{ANALYTICAL DISCUSSION AND THEORY}

The accounting items included in the DEA model should be carefully considered, since their weakness of lacking objectivity and a suitable benchmark, will to some extent be forwarded to the DEA model. From the literature study, the accounting line-items that were identified as possible DEA input and output variables are exhibited in Table 3. Although the literature indicates assets only as an input variable, the Du Pont analysis treats assets as both an input and output variable. Revenue is indicated by the literature only as an output variable, but the Du Pont analysis treats revenue as both an input and an output variable; therefore, to include revenue and assets in a DEA model, a three stage model is needed (Table 4).

Table 4: Input And Output Variables According To The Du Pont Analysis

\begin{tabular}{|c|c|c|c|}
\hline Stage one: Input & Stage one: Output & Stage two: Output & Stage three: Output \\
\hline Equity & Assets & Revenue & Profit \\
\hline
\end{tabular}

A three stage DEA model is clumsy and for each stage using only a single input and a single output, the results will be exactly the same as using three accounting ratios, - one for each of the three stages. To benefit from the strength of a DEA model, namely to aggregate the performance of firms in a single factor where multiple inputs 
and multiple outputs are used which is superior to a single input/output ratio, the challenge is to reduce the number of stages and to include more variables.

Using the data in Table 4, a two-stage model can be developed either with equity and assets as the first stage input with revenue as the output and profit as the output for the second stage, or equity as the input for the first stage with assets the output and both revenue and profit as the second stage's output. The logic from these two possible two-stage models, where the outputs of the first stage automatically form the inputs of the second stage, is that assets should rather be an input than an output and that revenue should be an output rather than an input. (Assets are implied twice as an input and once as an output, whilst revenue is once an input and twice an output.) Thus, including the above four items (Equation 3 of the Du Pont analysis) in a single stage model, equity and assets should be input variables with revenue and profit as output variables.

The above four items will form the core of the new DEA model. Further analysis has shown that liabilities and expenditure are also part of the Du Pont analysis (Equation 6), and from the literature review, the following variables can also be added, namely leverage (input), liquidity (input) and growth (output).

The above-mentioned nine variables will be used as a basis for developing a new DEA model. This variety of variables will be used as multiple inputs and multiple outputs. This will provide more substance than for example a single input with a single output model and will provide more discriminating power (Theunissen 2012; Avkiran, 1999) to estimate the relative efficiency of firms. It must be kept in mind that the model should be limited to a sensible number of variables, because the literature suggests that the variables included in a DEA model should be limited depending on the number of DMUs (firms) that are included in the sample. For example, Avkiran (1999) and Dyson et al. (2001) suggest that the sample size should be at least three (number of input variables + number of output variables) and two (number of input variables x number of output variables), respectively.

The three components of the Du Pont analysis capital structure, investment, and income will now be used as a framework to develop a new DEA model.

\section{Capital Structure (Asset/Equity In Equation 3)}

The components involved are equity, liabilities, assets and leverage. Although both equity and liabilities are needed to acquire assets, employing them as input variables and assets as an output is not logical because any combination of equity and liabilities equals the sum of assets and furthermore, the effect of leverage is not taken into account. Keeping in mind that the aim of a DEA model is to measure efficiency that require low inputs and high outputs to be efficient, as input variable it makes sense to lower liabilities and to increase assets, but it is not sensible to try to lower equity, on the contrary, the aim should be to increase equity - to create value for shareholders and to improve leverage. The suggestion is firstly not to use assets as an output (since any combination of equity + liabilities = assets), and secondly, rather to replace equity and liabilities with the Weighted Average Cost of Capital (WACC) since no firms strive to lower equity. WACC consists of the cost of equity, that is the expected rate of return that compensate for the shareholders' risk, and cost of long term debt. According to the trade-off theory (Correia et al., 2011; Brigham \& Ehrhardt, 2006; Vigario, 2005), the closer firms move to the optimal capital structure (debt/equity ratio), the lower their WACC will be. According to this theory firms will strive to operate with the lowest possible WACC. Note that WACC is not an accounting line-item and includes external elements, because the cost of equity is the rate what the market requires to compensate for risk and cost of debt (interest) is primarily a function of the economic environment (Correia et al., 2011; Brigham \& Ehrhardt).

Some may argue that although WACC is helpful to arrive at the optimal capital structure, many companies try to avoid debt (Correia et al., 2011) since it increases the unsystematic diversifiable risk of firms; therefore, the suggestion is to also employ leverage as an input variable. Since leverage is an input variable, the respective fraction should aim for a low teller and a high denominator. Any of the following equations may; therefore, be used: liabilities/equity or liabilities/assets. The latter leverage equation to some extent, automatically involve assets as an input variable, and this is also the case with the former, since liabilities = assets - equity. (Note that leverage may also be used as an output variable when the reciprocal values of the above equations are used, namely equity/liabilities or assets/liabilities.) 
Some may also argue that the cost of debt in the WACC represents only long term debt and no short term debt. Since liabilities may exist of a significant amount of current liabilities (short term debt), to compensate for ignoring current liabilities, the suggestion is again to employ leverage as an input variable. The reason is that leverage includes liabilities, which consist of both short and long term debt.

\section{Investment (revenue/assets in Equation 3)}

The Du Pont analysis indicated both revenue and assets as both input and output variables. Since assets are the input for the second stage and revenue the input for the third stage, the former is preferred in a single stage DEA model as the input to generate revenue as an output. Again, the suggestion is not to employ assets as an input variable; it is already indicated that assets cannot be an input together with WACC that represents liabilities and equity, and furthermore, to employ assets as an input implies that firms would strive to lower asset value, on the contrary, firms would aim to increase asset value.

\section{Income (profit/revenue in Equation 3)}

Profit is the ultimate output, but it is a function of both revenue and expenditure. Since revenue cannot be both an input and an output in the DEA model, the suggestion is to employ expenditure as input to generate net profit as an output. Net profit consists of retained income and dividend payouts and; therefore, the growth of firms is the function of retained income. To accommodate the element of growth, employing asset growth will not be sensible, because that could be the result of adverse liability growth. Using net profit, which includes retained income and dividends, contains in the former an element of growth.

Although Edirisinghe and Zhang (2010) classify liquidity as an input variable, it can also be accommodated as an output variable by adding EBITDA to net profit as another output variable. To take liquidity into consideration, EBITDA is a measure of 'cash profit', since this is an accounting measure of operating cashflow and avoids contaminating the results by the effects of gearing (Correia et al., 2011). Alternatives such as free cash flow value or a cashflow ratio could also be considered in this regard.

Table 5 summarizes the findings of the study by exhibiting all the input and output variables for a DEA model.

Table 5: Input And Output Variables For A DEA Model

\begin{tabular}{|l|c|}
\hline Input & Output \\
\hline WACC & Revenue \\
Leverage ratio (liabilities/equity or liabilities/assets) & EBITDA \\
Expenditure & Net profit \\
\hline
\end{tabular}

Since the study is qualitative of nature, the researcher is the data gathering instrument where the research probes for a deeper understanding rather than a search for causal relationships. Peer researchers were approached to provide inputs in the interpretation and analytical thoughts (Nieuwenhuis, 2013b). The assistance of the peer researchers is an effort to increase the creditability and trustworthiness of the study.

\section{CONCLUSION}

The objective of the study was to unravel accounting line-items and/or ratios and/or other variables and follow a logical approach to develop an acceptable accounting-based DEA model. From the literature the following nine items were identified to be included in a DEA model, namely equity, liabilities, assets, leverage, expenditure, revenue, liquidity, growth and net profit. The Du Pont analysis was used as the conceptual framework as a basis to unravel accounting performance (Equation 3). The DEA model indicated in Table 5 represents the three components of the Du Pont analysis, namely capital structure, investment and income.

WACC and leverage represent the capital structure as input variables. As input variable firms that aim to lower WACC automatically moves closer to their optimal capital structure. Employing leverage, where two line- 
items are combined (liabilities/equity or liabilities/assets), as input variable is helpful to lower the unsystematic diversifiable risk of firms. The conclusion is for firms to be technical efficient; firms should use as little as possible inputs, cost of capital (WACC) and risk (leverage), to convert into the highest possible output, revenue and profits. Regarding investment, WACC represents liabilities and equity which is the sum of assets. To conclude, using WACC, firms are technical efficient when financing assets at the lowest possible cost (input) and converting them into the highest possible output, revenue. Income is represented by expenditure and revenue. In conclusion, to be technical efficient employing as little as possible expenditure (input) to be converted in as high as possible revenue (output). Furthermore, employing net profit as an output variable, growth is also accommodated since it contains retained income. Liquidity is also accommodated by employing EBITDA as a variation of profit.

The model exhibited in Table 5 includes four accounting line-items: expenditure, revenue, EBITDA and net profit, and leverage, which consist of two accounting line items expressed as a ratio, and WACC, which is a proxy for the line-items, equity and liabilities. The contribution of the study is by using only accounting line-items makes this model practical since the information is readily available. Furthermore, it is based on the well-known and widely understood Du Pont analysis. With this model the relative technical efficiency of firms can be estimated from an input or an output orientated approach to examine, for example, the extent to which inputs can be reduced while maintaining output levels, or to examine the extent to which output levels can be raised given the current input levels, respectively. Furthermore, the results can be used to benchmark the internal performance of firms against rivals included in the sample.

The originality of this study is that this is the first effort to employ primarily accounting line-items, based on the Du Pont analysis in a DEA model. All the input and output variables in the model (Table 5) have already been used individually or in combinations by previous studies, except for WACC. This is the first study that argues that WACC should be employed as a proxy for equity and liabilities, since lower WACC implies firms moving closer to their optimal capital structure and reducing equity should not be an option to firms. WACC is not an accounting line-item and it contains external elements, but is readily available from data bases.

An approach of inductive reasoning was used where existing theories, mainly the Du Pont analysis and trade-off theory, were used to build a new specific DEA model. To introduce it as a possible new theory it should first be tested empirically; therefore, an additional study is recommended to do this testing. Further studies that can develop thereafter is firstly, to use this model as a first stage where the outputs are the inputs for the second stage that estimating market efficiency. Secondly, the results of this study's model can be compared with other performance measures of firms to test their validity.

\section{AUTHOR INFORMATION}

Professor Merwe Oberholzer is currently Professor in the School of Accounting Sciences at the North-West University (South Africa). He has taught extensively in the Chartered Accountancy and Chartered Management Accountancy programs. His academic research output includes more than 40 peer-reviewed articles and conference presentations. His current research focuses on performance management, corporate resilience and sustainability. Email: Merwe.Oberholzer@nwu.ac.za

\section{REFERENCES}

1. Abad, C., Thore, S.A. \& Laffarga, J. (2004). Fundamental analysis of stocks by two-stage DEA. Managerial and Decision Economics, 25: 231-241. Retrieved from www.interscience.wiley.com (DOI: 10.1002/mde.1145)

2. Ablanedo-Rosas, J., Gao, H., Zheng, X., Alidaee, B. \& Wang, H. (2010). A Study Of The Relative Efficiency Of Chinese Ports: A financial ratio-based data envelopment analysis approach. Expert Systems, 27(5): 349-361.

3. Agarwal, V. \& Taffler, R. (2008). Comparing the performance of market-based and accounting-based bankruptcy prediction models. Journal of Banking \& Finance, 32: 1541-1551. Retrieved from www.sciencedirect.com (doi: 10.1016/j.bankfin.2007.07.-14) 
4. Alvandi, M., Fazli, S. \& HashemiSiavoshani, A. (2013). Combination value investing and momentum investing to stock selection using data envelopment analysis. International Research Journal of Applied and Basic Sciences, 4(3): 741-746. Retrieved from www.irjabs.com

5. Anderson, T. (1996). A data envelopment analysis (DEA) Homepage. Retrieved from http://www.emp.pdx.edu.dea/homedea.html/

6. Asaftei, G. (2008). The contribution of product mix versus efficiency and technical efficiency change in US banking. Journal of Banking \& Finance, 32: 2336-2345. Retrieved from: www.sciencedirect.com

7. Asmild, M., Paradi, J.C. \& Kulkarni, A. (2006). Using data envelopment analysis in software development productivity measurement. Software Process Improvement and Practice, 11: 561-572. Retrieved from www.interscience.wiley.com (DOI: 10.1002/spip.298)

8. Avkiran, N. (1999). An application reference for data envelopment analysis in branch banking: Helping the novice researcher. International Journal of Bank Marketing, 17(5): 206-220.

9. Avkiran, N.K. (2011). Association of DEA super-efficiency estimates with financial ratios: investing the case of Chinese banks. Omega, 39(2011): 323-334. Retrieved from www.elsevier.com/locate/omega

10. Avkiran, N.K. \& Rowlands, T. (2008). How to better identify the true managerial performance: state of the art using DEA. Omega: The International Journal of Management Science, 36: 317-324.

11. Banker, R.D., Charnes, A. \& Cooper, W.W. (1984). Some models for estimating technical and scale efficiencies in data envelopment analysis. Management Science, 30(9): 1078-1092.

12. Berger, A.N. \& Humphrey, D.B. (1997). Efficiency of financial institutions: international survey and directions for further research, European Journal of Operational Research, 98: 175-212.

13. Bowlin, W.F. \& Renner, C.J. (2008). Assessing gender and top-management-team pay in the s\&p mid-cap and small-cap companies using data envelopment analysis. European Journal of Operational Research, 185: 430-437.

14. Brigham, E.F. \& Ehrhardt, M.C. (2006). Financial management. Mason, Ohio: Thomson.

15. Charnes, A., Cooper, W.W. \& Rhodes, E. (1978). Measuring efficiency of decision-making units. European Journal of Operations Research, 2: 429-444.

16. Chen, T. (2002). Measuring firm performance with DEA and prior information in Taiwan's banks. Applied Economic Letters, 9(3): 201-204.

17. Chiu, Y-H., Huang, C-W. \& Ting, C-T. (2011). Trade efficiency and development: evidence from a cross country comparison. Applied Economics, 40: 2749-2764.

18. Coelli, T.J., Rao, D.S.P., O’Donnel, C.J. \& Battese, G.E. (2005). An introduction to efficiency and productivity analysis. New York: Springer.

19. Collins English Dictionary . (2003). Complete and unabridged. HarperCollins Publishers. Retrieved from: <a href="http://www.thefreedictionary.com/nonparametric+statistics" > nonparametric statistics</a >

20. Cordeiro, J.J., Mukherjee, P. \& Kent, D.D. (2006). Non-parametric assessment of CEO compensation practices. Management Research News, 29(5): 242-251.

21. Correia, C., Flynn, D., Uliana, E. \& Wormald, M. (2011). Financial management, Cape Town: Juta.

22. Cronje, J.J.L. (2002). Data envelopment analysis as a measure for technical efficiency measurement in banking - A Research Framework. Southern African Business Review, 6(2): 32-41.

23. Devaney, M. \& Weber, W.L. (2000). Productivity growth, market structure, and technological change: evidence from the rural banking sector, Applied Financial Economics, 10: 587-595.

24. Dyson, R.G., Allen, R., Camanho, A.S. Podinovski, V.V., Sarrico, C.S. \& Shale, E.A. (2001). Pitfalls and protocols in DEA. European Journal of Operational Research, 132: 245-259.

25. Edirisinghe, N.C.P. \& Zhang, X. (2007). Generalized DEA model of fundamental analysis and its application to portfolio optimization. Journal of Banking \& Finance, 31: 3311-3335. Retrieved from www.elsevier.com/locate/jbf (doi: 10.1016/j.jbankfin.2007.04.008)

26. Edirisinghe, N.C.P. \& Zhang, X. (2010). Input/ output selection in DEA under expert information, with application to financial markets. European Journal of Operational Research, 207(2010): 1669-1678. Retrieved from www.elsevier.com/locate/ejor (doi:10.1016/j.ejor.2010.06.027)

27. EL-Mahgary, S. \& Lahdelma, R. (1995). Data envelopment analysis: visualizing the results. European Journal of Operational Research, 85: 700-710.

28. Farrell, M.J. (1957). The measurement of productive efficiency. Journal of the Royal Statistical Society, 120(3): 253-290. 
29. Frijns, B., Margaritis, D. \& Psillaki, M. (2012). Firm efficiency and stock returns. J Prod Anal, 37(2012): 295-306. (DOI 19.1007/s11123-011-0246-y)

30. Gaganis, C., Hasan, I. \& Pasiouras, F. (2013). Efficiency and stock returns: evidence from the insurance industry. Journal of Production Analysis. (DOI 10.1007/s11123-013-0347-x)

31. Guzmán, I. \& Arcas, N. (2008). The usefulness of accounting information in the measurement of technical efficiency in agricultural cooperatives. Annals of Public and Cooperative Economics, 79(1): 107-131.

32. Halkos, G.E. \& Salamouris, S. (2004). Efficiency measurement of the greek commercial banks with the use of financial ratios: a data envelopment analysis approach. Management Accounting Research, 15(2): 201224.

33. Hassan Al-Tamimi, H.A. \& Lootah, A.M. (2007). Evaluating the operational and profitability efficiency of a UAE-based commercial bank. Journal of Financial Services Marketing, 11(4): 333-348.

34. Ho, C-T.B. \& Oh, K.B. (2010). selecting internet stocks using a combined DEA and AHP approach. International Journal of System Science, 41(3): 325-336.

35. Ho, C-T.B., Wu, D.D., Chou, C. \& Olson, D.L. (2009). A risk scoring model and application to measuring internet stock performance. International Journal of Information Technology and Decision Making, 8(1): 133-149.

36. Javanmardi, L. \& Lawryshyn, Y. (2010). Stock selection by means of DEA and stochastic dominance. Global Economy and Finance Journal, 3(1): 1-13.

37. Kao, C. \& Hwang, S-N. (2008). efficiency decomposition in two-stage data envelopment analysis: an application to non-life insurance companies in Taiwan. European Journal of operational Research, 185(2008): 418-429. Retrieved from www.sciencedirect.com (doi: 10.1016/j.ejor.2006.11.041)

38. Kuo, R.J., Wang, Y.C. \& Tien, F.C. (2010). integration of artificial neural network and mada methods for green supplier selection. Journal of Cleaner Production, 18(12): 1161-1170.

39. Lee, Y-C., Hu, J-L. \& Ko, J-F. (2008). The effect of iso certification on managerial efficiency and financial performance: an empirical study of manufacturing firms. International Journal of Management, 25(1): 166174.

40. Liu, S-T. \& Wang, R-T. (2009). Efficiency measures of PCB manufacturing firms using rational two-stage data envelopment analysis. Expert Systems with Application, 36 (2009): 4935-4939. Retrieved from www.elsevier.com/locate/eswa

41. Lo, S.F. \& Lu, W.M. (2006). Does size matter? Finding the profitability and marketability benchmark of financial holding companies. Journal of Operational Research, 23(2): 229-246.

42. Luo, X. (2003). Evaluating the profitability and marketability efficiency of large banks: an application of data envelopment analysis. Journal of Business Research, 56: 627-635.

43. Malhotra, R., Malhotra, D.K. \& Lafond, C.A. (2008). Analyzing financial services industry using data envelopment analysis. Decision Sciences, 2123-2126. Retrieved from http://www.decisionsciences. org/Proceedings/DSI2008/doc/275-8511.pdf)

44. Maree, K. \& Van der Westhuizen, C. (2013). Planning research proposal. (In Maree, K., ed. First steps in research. Pretoria: Van Schaik. p. 24-46).

45. Min, H., Min, H., Joo, S.J. \& Kim, J. (2009). Evaluating the financial performance of Korean luxury hotels using data envelopment analysis. The Service Industries Journal, 29(6): 835-845.

46. Mouton, J. (2011). How to succeed in your Master's \& Doctoral studies: A South African guide and resource book. Pretoria: Van Schaik.

47. Munksgaard, J., Wier, M., Lenzen, M. \& Dey, C. (2005). Using input-output analysis to measure the environmental pressure of usage of different spatial levels. Journal of Industrial Ecology, 9(1-2): 169-185.

48. Murthy, D.S., Sudha, M., Hegde, M.R. \& Dakshinamoothy, V. (2009). Technical efficiency and its determinants in tomato production in Karnataka, India: data envelopment (DEA) approach. Agricultural Economics Research Review, 22: 215-224.

49. Myburg, J.E., Fouché, J.P. \& Cloete, M. (2011). Accounting: An introduction. Durban: LexisNexis.

50. Nieuwenhuis, J. (2013a). Introducing qualitative research. (In Maree, K., ed. First steps in research. Pretoria: Van Schaik. p. 47-69).

51. Nieuwenhuis, J. (2013b). Qualitative research design and data gathering techniques. (In Maree, K., ed. First steps in research. Pretoria: Van Schaik. p. 70-98).

52. Oberholzer, M. (2012a). The relative importance of financial ratios in the creation of shareholders' wealth. South African Journal of Economic and Management Sciences, 15(4): 416-428. 
53. Oberholzer, M. (2012b). The efficiency of south african mining companies to create shareholder and stakeholder value from environmental exploitation. Studia UBB Oeconomica, 57(2): 70-82.

54. Oberholzer, M. (2013). A non-parametric comparison among firms' income statement-based and balance sheet-based performance. International Business \& Economics Research Journal, 12(11): 1467-1478. Retrieved from http://journals.cluteonline.com/index. php/IBER/article/view/8183/8222

55. O'Donnell, C.J. \& Van der Westhuizen, G. 2002. Regional comparisons of banking performance in South Africa, The South African Journal of Economics, 70(3): 485-518.

56. Paradi, J.C., Rouatt, S. Zhu, H. (2011). Two-stage evaluation of bank branch efficiency using data envelopment analysis. Omega, 39(2011): 99-109. Retrieved from www.elsevier.com/locate/omega

57. Pätäri, E.J., Leivo, T.H. \& Honkapuro, J.V.S. (2010). Enhancement of value portfolio performance using data envelopment analysis. Studies in Economics and Finance, 27(3): 223-246. Retrieved from www.emaraldinsight.com/1086-7376.htm

58. Ray, S.C. (2004). Data envelopment analysis: Theory and techniques for economics and operational research. Cambridge University Press: Cambridge.

59. Resti, A. 1997. Evaluating the cost-efficiency of the Italian banking system: what can be learned from joint application of parametric and non-parametric techniques? Journal of Banking and Finance, 21: 221-250.

60. Seinford, L.M. \& Zhu, J. (1999). Profitability and marketability of the top 55 US commercial banks. Management Science, 45(9): 1270-1288.

61. Sherman, H.D. \& Gold, F. (1985). Bank branch operating efficiency: evaluation with data envelopment analysis. Journal of Banking and Finance, 9: 297-315.

62. Sherman, H.D. \& Ladino, G. (1995). Managing bank productivity: using data envelopment analysis (DEA). Interfaces, 25: 60-73.

63. Theunissen, M. \& Oberholzer, M. (2013). An application of data envelopment analysis to benchmark ceo remuneration: a South African study. Journal of Applied Business Research, 29(5): 1509-1522. Retrieved from http://journals.cluteonline.com/index.php/ JABR/article/view/8032/8086

64. Theunissen, M. (2012). An application of Data Envelopment Analysis to benchmark CEO remuneration. MCom mini-dissertation, North-West University: Potchefstroom.

65. Tsai, H.C., Chen, C.M. \& Tzeng, G.H. (2006). The comparative productivity efficiency for global telecoms. International Journal of Production Economics, 103: 509-526.

66. Van der Westhuizen, G. (2008). Estimating technical and scale efficiency and sources of efficiency change in banks using balance sheet data: a South African study, Studies in Economics and Econometrics, 32(1): 23-45.

67. Vigario, F. (2005). Managerial finance. 3rd edition. LexisNexis/Butterworths: Durban.

68. Wang, R-T., Ho, S-T.B. \& Oh, K. (2010). Measuring production and marketing efficiency using grey relation analysis and data envelopment analysis. International Journal of Production Research, 48(1): 183199.

69. Wier, M., Christoffersen, L.B., Jensen, T.S., Pedersen, O.G., Keiding, H. \& Munksgaard, J. (2005). Evaluating sustainability of household usage - using DEA to assess environmental performance. Economic System Research, 17(4): 425-447.

70. Yeh, Q. (1996). The application of data envelopment analysis in conjunction with financial ratios for bank performance evaluation. Journal of the Operational Research Society, 47: 980-988.

71. Yu, Y. \& Wen, Z. (2010). Evaluating China's urban environmental sustainability with data envelopment analysis. Ecological Economics, 69: 1748-1755.

72. Zhu, J. (2000). Multi-factor performance measure model with an application to Fortune 500 companies. European Journal of Operational Research, 123(2000): 105-124. Retrieved from www.elsevier.com/locate/orms

73. Zhu, J. (2009). Quantitative models for performance evaluation and benchmarking: Data envelopment with spreadsheets and DEA Excel Solver. New York: Springer. 